\title{
Discovering a 'Hidden' Collection: Early Printed Books and Old Master Prints in the McGill Library Collected by T.W. Mussen
}

\section{by Svetlana Kochkina}

\begin{abstract}
Thomas W. Mussen (1832-1901) was the rector of the Anglican Church at West Farnham, Québec from 1859 to 1901, and bequeathed his collection of old master prints and early printed books to McGill University. This article describes a special project undertaken by the author in order to reconstruct the collection that has long remained hidden from the research community. This article analyses the book collection under language (5 categories), place of publication (3), date of publication (7), and subject (8) and demonstrates the uniqueness of the collection by comparing it to the holdings of other Canadian libraries.
\end{abstract}

\section{RESUMÉ}

Thomas W. Mussen (1832-1901) était le recteur de l'église anglicane à West Farnham, Québec de 1859 à 1901 qui a légué sa collection d'estampes et livres rares à l'Université McGill. Cet article décrit le projet spécial entrepris par l'auteur dans le but de reconstruire de sa collection longtemps cachée de la communauté de recherche. Cet article analyse la collection de livres en fonction de la langue ( 5 catégories), du lieu de publication (3), de la date de publication (7), et des sujets (8) et prouve le caractère unique de sa collection en la comparant aux fonds des autres bibliothèques canadiennes.

\section{I}

The problem often referred to as 'hidden collections' - that is, those that are uncatalogued, poorly catalogued, unprocessed, or lacking online access - is not something exclusive to the McGill Library. They were the topic of an ARL Task Force (2001-2006) that resulted in the well-known paper "Hidden Collections, Scholarly Barriers," by Barbara Jones published later in the RBM: A Journal of Rare Books, Manuscripts, and Cultural Heritage. ${ }^{1}$ Since the publication of this paper, a considerable body of scholarly and professional literature has appeared, where the threats and hindrances that the issue represents to scholarly research and to the collections themselves, as well as ways of solving this problem on a large or a local scale, have been discussed. An excellent review of the literature on the subject has been offered in the article by Melissa A. Hubbard and Ann K. D. Myers "Bringing Rare Books to Light: The State of the Profession". Despite the efforts of the library community, hidden collections remain a pertinent issue for almost every academic library that has extensive holdings in rare books and special collections. The current article does not offer a solution to this problem, but describes a project aiming to improve access to a particularly interesting example of such a collection: the early printed books and old master prints donated to the McGill Library by the family of T.W. Mussen.

In fact, the Mussen collection is almost a perfect example of a hidden collection because it has suffered or is suffering from most of the problems identified by Barbara M. Jones: ${ }^{3}$

- it is not kept together physically or bibliographically as a separate collection

- wider scholarly community is unaware of existence of many of the items due to the lack of online access. None of the prints and only some books are in McGill online catalogue. Consequently, most of the items from Mussen collection do not appear in AMICUS and WorldCat

- access to the collection as a whole is staffdependent and is threatened by the inevitable loss of institutional memory: the author of the present article learned about this collection in conversation with the Head and Curator of Manuscripts of Rare Books and Special Collections, Dr. Richard E. Virr

+ $\quad$ existing manual finding aides, such as the Rare Books and Special Collections' (RBSC hereafter) 
list of European prints, are extremely difficult to use especially for inexperienced researchers more accustomed to online tools

- print collection is subject to the wear of physical items: due to lack of finding aids, staff have to look through many prints in order to find a particular print

Most importantly perhaps, the existence of the collection has not been documented in any of the widely accessible information sources. The physical collection has been dispersed, and provenance information was found in only 16 catalogue records, one of which had misspelled Mussen's name. To summarise, there is nothing that alerts a researcher to the existence of the Mussen collection, nor is there any way of identifying most Mussen items, despite the historical value of the collection, and the research importance of many individual items.

The collection is potentially of research value to scholars in church history, theology, art history, and library and book history. According to AMICUS, the Canadian national union catalogue, most of the Mussen's books are unique copies in Canada (See section V below), with some being particularly rare such as an exquisitely illuminated folio of Decretum Gratiani, the first dated book printed in Strasburg in 1472 by Heinrich Eggestein, an apprentice of Gutenberg. ${ }^{4}$ In addition to the research value of many individual items, the collection as a whole can serve as a case study on $19^{\text {th }}$ century collectors outside of the main Quebec urban areas.

\section{II}

The collection's creator, Rev. Thomas W.Mussen(1832-1901) was the son of Thomas Mussen, ${ }^{5}$ a well-known Montreal drygoods merchant. ${ }^{6}$ After ordination, he was appointed rector in 1859 of the Anglican Church at West Farnham. Being successful in his duties as a rector, he became later a Rural Dean of Bedford and a Canon of Christ Church Cathedral at West Farnham. During his appointment, Mussen made the parish financially independent, enlarged the church, and constructed a new rectory and parish hall that he designed himself. The complex of Saint-James the Apostle and Martyr Church is listed in the Canadian Register of Historic Places and the Répertoire du patrimoine culturel du Québec. ${ }^{7}$ Mussen was described in the History of Diocese of Montreal as "a man of culture and erudition," with a good knowledge of Latin, Greek, and Hebrew and a "lover of Art", who "possessed a large collection of coins and engravings by the old Masters, also a rare collection of old books." The bulk of this collection was purchased during his grand tour of Europe in 18561858. Although at his death in 1901 Mussen did not leave any formal bequest, he had expressed the wish that his collection be donated to McGill University, ${ }^{9}$ the institution where he began his higher education. ${ }^{10}$ Consequently, the major part of his collection of early printed books, old master prints, and
Greek and Roman coins was donated in 1919 to the McGill Library by his widow and daughter, Mrs. Mussen and Miss Caroline E. Mussen, while a second, less significant, donation was made in 1941.

The 1919 donation was recognised at the time as "an exceptional gift" in the Montreal Gazette. ${ }^{11}$ The collection included, among other items, seven incunabula and prints by Durer (e.g. the famous Four Horseman of Apocalypse), Lucas van Leyden (e.g. Saint Madeleine), and Rembrandt (e.g. The Descent from the Cross), the latter of which was the subject of an article by Maria L. Brendel. ${ }^{12}$ Regrettably, although this collection was recognised as "one of the most important additions which the Library has received in many years,"13 it was not kept together as a separate entity. The Mussen's Greek and Roman coins collection was described in 1991 by Richard E. Virr et al. published in Fontanus, ${ }^{14}$ and this new project was undertaken to reconstruct the remaining Mussen prints and book collections.

\section{III}

In reconstructing the collection, the author was advised and guided by Dr. Richard Virr, with the goal of identifying, describing, analysing, and making accessible to the public a collection of the rare prints and early books donated to the McGill Library by T.W. Mussen and his family.

Access to the Mussen prints was difficult and incomplete as there is no comprehensive donation list, or records in the online catalogue. An approximate figure, "over 110 early engravings" is given in the Quarterly and Annual Report of the Librarian, 1917-1920..$^{15}$ Some of the Mussen prints have been included in the Rare Books and Special Collections "European Prints" typewritten listing, along with other prints, listed and numbered according to their order in the physical collection. At the time, the most complete inventory of prints was a carbon copy of the pages numbered 3 and 4 of a type-written inventory, "Mussen Memorial", which listed a portion of the prints and was found in the Thomas Mussen file. ${ }^{16}$ However, no references were found from the "Mussen Memorial" list to "European Prints", so the Mussen prints were almost unfindable in the physical collection. The Mussen Memorial list (M.M.l. hereafter) contains 114 items, that are handnumbered from 1 to 83 (several items being grouped under one number), while 11 items are marked with "W" in the same hand-writing. There is a type-written note at the end of the list: "several other engravings, by unknown persons, and of less va[lue]". It can be assumed that the numbering was done during an inventory that took place sometime after the donation had been accepted by McGill, and "W" could mean "wanting" because none of the prints marked with "W" have been found.

In order to identify the Mussen prints, they were all crossreferenced against "European Prints, ${ }_{10}^{18}$ where some of them are listed in two separate sub-sections. A random search 
revealed that other Mussen prints are listed in "European Prints" but are identified only with difficulty after a timeconsuming search because of the ad hoc organisation of the catalogue. This listing has no index, and donors are identified randomly if at all. The entries in the catalogue are not in any alphabetical or other order. In addition, RBSC's possesses a large number of uncatalogued prints that do not appear in "European Prints", so this approach of cross-referencing was soon abandoned. Since all Mussen prints have a Mussen Memorial stamp and a number on the verso, and most of them have this own "Rev. T.W. Mussen" label, they can be easily identified by examining the physical items. A decision was made to examine physically the entire collection of European prints amounting to 1,605 catalogued and more than 900 uncatalogued items.

As a result, a comprehensive catalogue of Mussen's prints has been compiled: 112 prints, including 98 appearing in the Mussen Memorial list and 14 not included in the list, with 16 identified as missing. A short description has been provided for all uncatalogued prints, and authority work has been done using, among other sources, the database of the RKD (Rijksbureau voor Kunsthistorische Documentatie/ Netherlands Institute for Art History), ${ }^{19}$ Grove Art Online, and Oxford Art Online. Finally, some basic conservation measures were taken to protect several fragile prints.

\section{IV}

The next stage of the project was identification of Mussen books, catalogued and uncatalogued, in the McGill Library. As no list of the books donated to McGill was found, the potential total was unknown. For technical reasons, the Library's accession registers were unavailable for consultation until late in the project. At the time, the McGill online catalogue identified in notes only 16 books as donated by T.W. Mussen or by his daughter, Miss C.E. Mussen. The most comprehensive inventory was a shelf-list, a small binder with $3 \times 5$ hand-written cards listing the 46 oldest and most valuable Mussen books. However, a comparison of online search results and the shelf-list revealed that there is no complete overlap between them, indicating that neither can be considered exhaustive.

To compile a comprehensive list of Mussen book collection the McGill University Archives were consulted. The carbon copies of three letters were located in the Library's Outgoing Letter Book from the University Librarian, Charles $\mathrm{H}$. Gould, to Mrs. and Miss Mussen..$^{20}$ These letters confirmed the existence of typewritten list of the first lot of books donated to McGill Library in the beginning of January $1919^{21}$ - possibly pages 1 and 2 of the Mussen Memorial list. Also, they permitted identification of some Mussen books, because the letters from January 31, $1919^{22}$ and February 10, $1919^{23}$ listed the second and third lots of books. In addition, these letters led to an article "Notable gifts to M'Gill library" about the donation that was published in the Montreal Gazette in $1919 .{ }^{24}$ Examination of the McGill University Annual Report of the Governors, Principal, and Fellows for the year 1918-1919 established the total number of volumes donated to the McGill Library in 1919- "76 volumes, consisting of early printed works, many of them of great value."25 It should be noted that the number 76 could be interpreted in two ways: first and most probably, as a number of titles given to the library, second, as number of physical volumes. For the purpose of this research, it is assumed that the number " 76 " represents the number of individual titles donated to the McGill Library by the Mussen family and not a number of physical volumes constituting multivolume sets.

By comparing information from the University Librarian letters, the $3 \times 5$ cards binder, RBSC card catalogue, McGill Library online catalogue, and McGill Library accession registers, 73 titles of 76 , donated to the McGill Library by the Mussen family in 1919, were identified. Later, eight more titles previously belonging to T.W. Mussen have been found. The date of donation of those eight books cannot be confirmed by any archival evidence but can be established as before 1940 according to the accession information. Of 81 titles 74 physical books have been located. The provenance of all the books has been confirmed by examining the physical copies for the presence of the donor plate, donor stamp, T.W. Mussen's bookplate, or his signature.

When the identification of the books donated to the McGill Library in 1919 was nearly completed, an unsigned one-page draft document, Presentations to the Redpath Library June-1941 19 was discovered by RBSC's Curator of Manuscripts in a document file. This document suggested that another donation was expected in 1941 from the estate of the late Miss Caroline E. Mussen. However, in the Annual Report 1941-194227, the total number of accepted books from Miss Mussen estate is not given, and there are no references to the donated prints or to the overall size and to any value of the donation. Examination of the accession registers for the years 1940-1947 (1947 being the last register preserved) has revealed that only $\operatorname{six}^{28}$ titles from Miss Mussen's estate were placed in the Library's collection during the period 1941-1947. The McGill Archives produced no list of donated books either in the correspondence files or in the Annual Report 1941-1942. ${ }^{29}$ The correspondence ${ }^{30}$ between Vice-President and Managing Director of the Crown Trust Company, J. Rexford, and University Librarian, G.R. Lomer, states that Miss C.E. Mussen's "will was made prior to 1919",31 and "all [her] rare and valuable books, engravings [...] and coins" ${ }^{\prime 2}$ mentioned in the will as bequeathed to McGill were already donated to McGill Library in January 1919, and "the records of the estate show a list of these books and a receipt".33 In addition, the references in the correspondence to the fact the books that are "not now selected by McGill go to the Montreal Diocesan Theological College" ${ }^{\prime 4}$ also support the assumption that the total number of items from the Mussen 
collection accepted by the McGill Library in 1941 was not significant.

\section{V}

Despite the fact that it has been impossible to reconstitute the entire Mussen book collection ${ }^{35}$, the description of 87 titles donated in 1919 and 1941 gives an understanding of the scope of the collection. Some of the most interesting books include the previously mentioned Decretum Gratiani (1482), a folio magnificently illuminated with floral motives; Compendium de Origine et Gestis Francorum (1497) by Robert Gaguin, renowned French Renaissance humanist and philosopher, the first work on the history of France breaking with the medieval historical tradition; a Venetian edition of the famous Canzoniere, Le Cose Volgari di Messer Francesco Petrarcha (1501), the first Italian book printed in italic type; an English translation of the Il Libro del Cortegiano (1577), the definitive account of Renaissance court life by Baldassare Castiglione, one of the most widely distributed books of the $16^{\text {th }}$ century; and Athanasii KircherieSoc.Jesu Chinamonumentis (1667), bound in vellum and richly illustrated with splendid engravings based on explorers' sketches and original images brought from Asia. The collection bears the evidence of Mussen's book collecting and bibliophilic practices. Mussen's 54 earliest books have his bookplate on the front pastedown. 11 books printed in $15^{\text {th }}$-early $17^{\text {th }}$ centuries, have laid within them correspondence with booksellers, newspaper clippings, or notes dealing with provenance, other copies, value, or rarity of the book: an example is Mammotrectus Super Bibliam (1487).

At present, the collection is composed of 87 titles, including eight titles bound together in three volumes. ${ }^{36}$ The majority of the books , 61 early printed books and 7 incunabula, which constitute $78.2 \%$ of the collection, were printed in the hand printing-press period, before 1850 , and almost $50 \%$ of the collection is comprised of the pre- $18^{\text {th }}$ century imprints (see Table 1). ${ }^{37}$

Table 1

\begin{tabular}{|l|l|l|}
\hline Date & \# Titles & \% \\
\hline $1472-1500$ & 7 & 8.1 \\
\hline $1501-1600$ & 21 & 24.2 \\
\hline $1601-1700$ & 15 & 17.2 \\
\hline $1701-1800$ & 15 & 17.2 \\
\hline $1801-1850$ & 10 & 11.5 \\
\hline $1851-1900$ & 18 & 20.7 \\
\hline $1901-1999$ & 1 & 1.1 \\
\hline Total & 87 & 100 \\
\hline
\end{tabular}

In order to prove the uniqueness of the Mussen collection and thereby, its significance for the scholarly community, a comparative survey of the holdings in Canadian libraries has been undertaken. First, every title has been checked against the holdings of other Canadian libraries (same edition, date and place of publication), using AMICUS, ${ }^{38}$ the Canadian national union catalogue. A considerable amount of inaccuracy in the AMICUS records has been discovered with regard to the physical format of the items, (e.g. printed items have been found linked to microform records and vice versa). Therefore, the holdings of each library reported in AMICUS as owning copies of the titles included in the Mussen collection, have been verified using their local online catalogues. As a result of this survey, it can be concluded that the collection donated by the Mussen family to McGill is indeed a notable and exceptional gift ${ }^{39}$ and a valuable addition to the McGill Library collections since the majority of the books (58.6\%) constitutes unique holdings in Canada (see Table 2). It is necessary to acknowledge some limitations in the assessment of libraries' holding with use of AMICUS and the individual on-line catalogues, which are due to the existence of 'hidden collections' of uncatologued materials, mentioned earlier. However, at present, AMICUS, the Canadian national union catalogue, is the best available tool for the assessment of the frequency of the holdings in Canadian libraries. This survey can be repeated several years later when more collections that are presently 'hidden' and uncatalogued will be added in local on-line catalogues and, consequently, in AMICUS.

Table 2

\begin{tabular}{|l|l|l|}
\hline $\begin{array}{l}\text { Number of Holdings } \\
\text { Other than McGill }\end{array}$ & $\begin{array}{l}\text { No of } \\
\text { Titles }\end{array}$ & $\mathbf{\%}$ \\
\hline 0 libraries & 51 & 58.6 \\
\hline 1-3 libraries & 26 & 30 \\
\hline 4-6 libraries & 6 & 6.9 \\
\hline 6-10 libraries & 1 & 1.1 \\
\hline more than 10 libraries & 3 & 3.4 \\
\hline Total & 87 & 100 \\
\hline
\end{tabular}

Tables 3 and 4 below illustrate the relationship between languages and places of publication. The majority of the books (51.7\%) were published in continental Europe, which finds its reflection in the distribution of languages of publications because non-English (Latin, French, Italian, and Greek) books account for more than $50 \%$ of the collection. 
Table 3

\begin{tabular}{|l|l|l|}
\hline $\begin{array}{l}\text { Language of } \\
\text { Publication }\end{array}$ & $\begin{array}{l}\text { No of } \\
\text { Titles }\end{array}$ & $\mathbf{\%}$ \\
\hline English & 41 & 47.1 \\
\hline Latin & 32 & 36.8 \\
\hline French & 10 & 11.5 \\
\hline Italian & 2 & 2.3 \\
\hline Greek & 2 & 2.3 \\
\hline Total & 87 & 100 \\
\hline
\end{tabular}

Table 4

\begin{tabular}{|l|l|l|}
\hline $\begin{array}{l}\text { Place of } \\
\text { Publication }\end{array}$ & $\begin{array}{l}\text { No of } \\
\text { Titles }\end{array}$ & $\%$ \\
\hline Cont. Europe & 45 & 51.7 \\
\hline UK & 36 & 41.4 \\
\hline US & 6 & 6.9 \\
\hline Total & 87 & 100 \\
\hline
\end{tabular}

Finally, a subject analysis of the collection has been undertaken. Due to the small number of items in the collection, all titles have been grouped in seven wide subject categories largely corresponding to the subject areas of the Library of Congress Classification. The subject content of the collection is an excellent reflection of the professional and intellectual interests of its creator: a well-educated Anglican minister, known to read daily his Hebrew and Greek Bibles, "a lover of Art",40 and a collector of rare books. "Philosophy/ Religion" and "Literature" constitute almost half of his collection (see Table 5). Smaller but still significant proportions of the collection classified under "Geography, Exploration, Travel" and "Arts, Architecture, Design" represent other Mussen's important personal interests and pursuits. He was undoubtedly interested in traveling as he spent two years touring Europe, while his interest in architecture and design was even more important and practical. As it is mentioned above, Mussen was an amateur architect, who designed the complex of Saint-James the Apostle and Martyr Church in Farnham, included now in the Canadian Register of Historic Places and the Répertoire du patrimoine culturel du Québec (see Note 7). The exact match of the subject coverage of the collection with the proven interests, hobbies, and occupations of Mussen allows us to suppose that if a complete inventory of collection is ever discovered, the subject distribution will not significantly change.
Table 5

\begin{tabular}{|l|l|l|}
\hline $\begin{array}{l}\text { Subject } \\
\text { Group }\end{array}$ & $\begin{array}{l}\text { No of } \\
\text { Titles }\end{array}$ & \% \\
\hline $\begin{array}{l}\text { Philosophy, } \\
\text { Religion, Bibles }\end{array}$ & 24 & 27.7 \\
\hline Literature & 18 & 20.7 \\
\hline $\begin{array}{l}\text { Geography, } \\
\text { Exploration, Travel }\end{array}$ & 15 & 17.2 \\
\hline World History & 10 & 11.5 \\
\hline $\begin{array}{l}\text { Arts, Architecture, } \\
\text { Design }\end{array}$ & 9 & 10.3 \\
\hline Law & 6 & 6.9 \\
\hline $\begin{array}{l}\text { Science, Natural } \\
\text { Science }\end{array}$ & 5 & 5.7 \\
\hline Total & 87 & 100 \\
\hline
\end{tabular}

\section{VI}

At present, 112 Mussen prints housed at the McGill Library include 98 prints from the Mussen Memorial list and 14 prints not included in the list (see the discussion on the discovery of the collection in the Section III above). The collection comprises, among other items, the renowned Four Horseman of Apocalypse, Flight into Egypt, and Presentation in the Temple by Albrecht Durer; The Descent from the Cross, Portrait of Petrus van Tol, and Return of the Prodigal Son by Rembrandt; Prodigal Son by Sebald Beham; Sainte Madeleine by Lucas van Leyden; Christ with the Crown of Thorns by Van Dyck; and a number of prints by Lucas von Cranach, Cornelis Galle, Jacques Callot, and Hieronymus Cock. It must be noted that while it was not uncommon for collectors to purchase and collect prints cut out of early printed books, all Mussen's prints represent stand-alone items, produced and sold as separate prints. This provides another insight into Mussen's collecting practices and creates his image as of a scrupulous and conscientious prints collector.

A significant part of the collection (more than 90\%) consists of old master prints produced during the golden age of print-making, the $16^{\text {th }}$-the early $17^{\text {th }}$ centuries (see Table 6), which shows this was undoubtedly the period of Mussen's major collecting interest. 
Table 6

\begin{tabular}{|l|l|l|}
\hline Century & $\begin{array}{l}\text { No of } \\
\text { Prints }\end{array}$ & $\mathbf{\%}$ \\
\hline 16 th & 46 & 41 \\
\hline 17 th & 58 & 51.8 \\
\hline 18 th & 3 & 2.7 \\
\hline undefined & 5 & 4.5 \\
\hline Total & 112 & 100 \\
\hline
\end{tabular}

Mussen's collecting interest in earlier prints is also manifested in the proportional distribution of the schools of printmaking (see Table 7). The majority of prints (more than $60 \%$ of the collection) belong to the Northern schools, German and Dutch/Flemish, which were the most important in the early period of printmaking.

Table 7

\begin{tabular}{|l|l|l|}
\hline School & $\begin{array}{l}\text { No of } \\
\text { Prints }\end{array}$ & $\mathbf{\%}$ \\
\hline Dutch/ Flemish & 47 & 42 \\
\hline German & 21 & 18.8 \\
\hline French & 20 & 17.8 \\
\hline Italian & 19 & 16.9 \\
\hline Undefined & 5 & 4.5 \\
\hline Total & 112 & 100 \\
\hline
\end{tabular}

It is difficult to explain the small quantity of woodcuts in Mussen's collection (see Table 8). We could not attribute this small number to his lack of appreciation of this printmaking technique because the woodcuts present in his collection are of the uppermost value: of eight woodcuts four are of Albrech Durer and two of Lucas von Cranach. We can only speculate that the woodcuts might have been difficult to obtain or beyond his financial means.

Table 8

\begin{tabular}{|l|l|l|}
\hline Technique & $\begin{array}{l}\text { No of } \\
\text { Prints }\end{array}$ & $\mathbf{\%}$ \\
\hline Engraving & 74 & 66.1 \\
\hline Etching & 30 & 26.8 \\
\hline Woodcut & 8 & 7.1 \\
\hline Total & 112 & 100 \\
\hline
\end{tabular}

The subject matter of the prints collection, similarly to his book collection, reflects with striking accuracy the professional and intellectual interests of its former owner, an Anglican rector, interested in history with "Christianity, Bible" and "Ancient History/Mythology" constituting more than two thirds of his collection (see Table 9). The predominance of those subjects in the collection can also be attributed to his collecting interest in the old master prints, for which religion and ancient history and mythology were common subjects.

Table 9

\begin{tabular}{|l|l|l|}
\hline Subject & $\begin{array}{l}\text { No of } \\
\text { Prints }\end{array}$ & \% \\
\hline Christianity, Bible & 76 & 67.8 \\
\hline $\begin{array}{l}\text { Ancient History/ } \\
\text { Mythology }\end{array}$ & 18 & 16 \\
\hline Genre Scene & 7 & 6.3 \\
\hline Landscape & 5 & 4.5 \\
\hline Portrait & 5 & 4.5 \\
\hline Architectural Detail & 1 & 0.9 \\
\hline Total & 112 & 100 \\
\hline
\end{tabular}

\section{VII}

The process of discovering this collection leaves two questions unanswered. The first question is the size and content of the initial Mussen collection, i.e. its parts that were not donated or accepted in the McGill Library in 1919 or in 1941. Unfortunately, there is little probability that the rest of Mussen collection or its inventory can ever be discovered. Miss C.E. Mussen's estate was managed by the Crown Trust Company that failed in 1983. Its archives are not found either in Bibliothèque et Archives nationales du Québec (BAnQ) $)^{41}$ or in Library and Archives Canada ${ }^{42}$. It's possible that the papers of the Crown Trust Company may be held by the Canada Deposit Insurance Corporation, of which it was a member institution. ${ }^{43}$ However, even if located, the documents might not be made available for research due to the privacy concerns. Other probable sources of information could be either privately held papers or county archives. If further research on Mussen collection were undertaken, the next steps could include finding descendants of T.W. Mussen's nephew, Harold Beauford Mussen, son of William W. Mussen ${ }^{44}$ or the descendants of other branches of the Mussen family in addition to the known ones: Miss C.E. Mussen, daughter of the T.W. Mussen, who died childless in 1941; Henry S. Mussen, brother of T.W. Mussen, who died a bachelor in 1912.45 and Alexander Mussen, another brother, who went to Australia to try his luck on the goldfields and to escape the consequences of some disreputable behaviour 
and who was killed in 1864 at Lower Pyramul unmarried and childless. ${ }^{46}$

Another research avenue might shed light on the second unanswered question: the process of acquisition of the collection (dates, places, and ways of purchasing: in person or through the booksellers, etc.). T.W. Mussen kept diaries for the most of his life, the excerpts of which, dealing with his professional activities including acquisition, building, and enlarging of the church property in Western Farnham, were published in Missisquoi County Historical Society Reports in $1965-1980^{47}$ as a series of articles "Cannon Mussen's Diary" by late G.P. Hawke. The diaries (from March 31, 1855 to March 18, 1856 and from Dec. 27. 1876 to Sept. 4 1885) are kept at the Brome County Historical Society archives. ${ }^{48}$ Taking into account the detailed style of his diary entries, it may be supposed that he could have also been recording information about the books and the prints that he was collecting. Therefore, his diaries might prove to be a valuable source of information about the origins of the collection.

The subject of reading and collecting habits of Canadians and Quebecers in the $18^{\text {th }}$ and $19^{\text {th }}$ centuries has been actively pursued and successfully explored by several researchers, such as Patricia Fleming, Yvan Lamonde, Marcel Lajenesse, Gilles Gallichan, and Sophie Montreuil, to name just a few. ${ }^{49}$ A reconstructed Mussen collection offers researchers in Canadian history and in the history of the book in Canada yet another insight into collecting pursuits and reading interests of educated Montrealers and Quebecers of the $19^{\text {th }}$ century. The knowledge of and the interest in early printed books and old master prints, and the ability of a Quebec rural clergyman to collect them, demonstrated by the existence of the Mussen collection, could contribute to our understanding of Canadian and Quebec cultural reality at the time.

Finally, it should be said that working on the Mussen collection has permitted the author of this article to understand and even connect with the personality and mind of the person who created it-a passionate, knowledgeable, and focused collector. This experience demonstrates again the truthfulness of the quote by Sir William Osler: "A library represents the mind of its collector, his fancies and foibles, his strength and weakness, his prejudices and preferences. Particularly is this the case if, to the character of a collector, he adds-or tries to add-the qualities of a student who wishes to know the books and the lives of the men who wrote them. ${ }^{50}$

\section{Acknowledgments}

I am profoundly grateful to Dr. Richard E. Virr, Head and Curator of Manuscripts of McGill RBSC, for his advice and guidance through the project, as well as to Gordon Burr, Senior Archivist of McGill University Archives, for his support of this research. I would like also to thank my colleagues from McGill University, Megan Chellew, John Hobbins, Louisa
Piatti, and especially Professor Peter F. McNally for reading and commenting on the draft of this article.

\section{ENDNOTES}

${ }^{1}$ Barbara M. Jones, "Hidden Collections, Scholarly Barriers: Creating Access to Unprocessed Special Collections Materials in America's Research Libraries," RBM: A Journal of Rare Books, Manuscripts and Cultural Heritage 5, no. 2 (2004): 88-105.

${ }^{2}$ Melissa A. Hubbard and Ann K. D. Myers. "Bringing Rare Books to Light: The State of the Profession," RBM: A Journal of Rare Books, Manuscripts, and Cultural Heritage 11, no. 2 (2010): 134-51.

${ }^{3}$ Jones, "Hidden Collections, Scholarly Barriers: Creating Access to Unprocessed Special Collections Materials in America's Research Libraries," 88-105.

${ }^{4}$ Quarterly and Annual Report of the Librarian, 1917-1920. McGill University Archives, R.G. 40, c. 0033, file number 03307.

${ }^{5}$ Letter of 2 May 1941 to University Librarian G.R. Lomer from Crown Trust Company. Copy. Bequest of Mussen, Miss Caroline E. File. McGill University Archives, R.G. 40, c. 0233, file number 02650.

${ }^{6}$ William H. Atherton and Rodolphe Joubert, Montreal, 1535-1914 (Montreal: S. J. Clarke, 1914), v. 3, 209.

${ }^{7}$ More information about the complex of Saint-James the Apostle and Martyr Church can be found on the websites of the Canada's Historic Places http://historicplaces.ca/en/rep-reg/place-lieu.aspx?id=13275.

Répertoire du patrimoine culturel du Québec http://www.patrimoineculturel.gouv.qc.ca/rpcq/detail.do?methode=consulter\&id=120972\&type =bien, and Ville de Farnham http://www.ville.farnham.qc.ca/culture.htm

${ }^{8}$ Douglas J. Borthwick, History of the Diocese of Montreal, 1850-1910 (Montreal: J. Lovell, 1910), 121. Head and Curator of Manuscripts of Rare Books and Special Collections, Dr. Richard E. Virr referred the author to this resource.

${ }^{9}$ Quarterly and Annual Report of the Librarian, 1917-1920.

${ }^{10}$ Borthwick, History of the Diocese of Montreal, 119. Later, he studied the Ministry at the Lennoxville University after spending two years at McGill.

${ }^{11}$ “Notable Gifts to M'Gill Library.” Montreal Gazette, 15 February 1919.

${ }^{12}$ Maria Lydia Brendel, "Not a Bad 'Impression': A Fine 'Rembrandt' Print in McGill's Collection," Fontanus 10, (1998): 35-40.

${ }^{13}$ Quarterly and Annual Report of the Librarian, 1917-1920.

${ }^{14}$ Richard Edmund Virr, Barbara Lawson, Michael Woloch, and Franziska E. Shlosser, "The McGill University Collection of Greek and Roman Coins: New Evidence for Its History," Fontanus 4, (1991): 109-24.

${ }^{15}$ Quarterly and Annual Report of the Librarian, 1917-1920.

${ }^{16}$ T.W. Mussen File, Rare Books and Special Collection, McGill University.

${ }^{17}$ Mussen Memorial list, T.W. Mussen File, Rare Books and Special Collection, McGill University.

${ }^{18}$ European Prints Catalogue, Rare Books and Special Collection, McGill University.

${ }^{19}$ Database of RKD (Rijksbureau voor Kunsthistorische Documentatie/ Netherlands Institute for Art History) http://website.rkd.nl/home.

${ }^{20}$ University Librarian Charles H. Gould Letterbooks, March 7, 1918 to May 2, 1919, McGill University Archives, R.G. 40, c. 0060, file number 01620.

${ }^{21}$ Letter of 31 January 1919 to Mrs. T.W. Mussen from University Librarian Charles H. Gould. Gould Letterbooks, McGill University Archives, R.G. 40 c. 0060, file number 01620. See also Letter of 10 February 1919 to Miss C.E. Mussen from University Librarian Charles H. Gould. Gould Letterbooks, McGill University Archives, R.G. 40 c. 0060, file number 01620.

${ }^{22}$ Letter of 31 January 1919 to Mrs. T.W. Mussen from University Librarian Charles H. Gould. 
${ }^{23}$ Letter of 10 February 1919 to Miss C.E. Mussen from University Librarian Charles H. Gould.

${ }^{24}$ "Notable Gifts to M'Gill Library."

${ }^{25}$ McGill University Annual Report of the Governors, Principal, and Fellows for the Year 1918-1919, Montreal: McGill University, 1919.

${ }^{26}$ Presentations to the Redpath Library June-1941, Rare Books and Special Collection, McGill University. [Draft]

${ }^{27}$ Annual Report of the University Librarian, 1941-1942, McGill University Archives, R.G. 40, c. 0026, file number 02579.

${ }^{28}$ Accession Registers 1941-1947, Rare Books and Special Collection, McGill University.

${ }^{29}$ Annual Report of the University Librarian, 1941-1942.

${ }^{30}$ Bequest of Mussen, Miss Caroline E. File, McGill University Archives, R.G. 40, c. 0233 , file number 02650.

${ }^{31}$ Letter of 2 May 1941 to University Librarian G.R. Lomer from Crown Trust Company.

${ }^{32}$ Ibid.

${ }^{33}$ Ibid.

${ }^{34}$ Ibid.

${ }^{35}$ Most of the Mussen's books not accepted by the McGill Library and donated to the Montreal Diocesan Theological College in 1941 might have ended up in the McGill Library collection when the College library was transferred to the McGill Library. However, those books cannot be located as their initial provenance had not been traced.

${ }^{36}$ Eight bound-together titles include 2 incunabula, 4 titles published in the 16 th century, and 2 titles published in the 17 th century.

${ }^{37}$ It must be taken into account that should the inventory of the whole collection is ever discovered and become available for analysis, the proportional distribution of places and dates of publication might change.

${ }^{38}$ AMICUS. http://www.collectionscanada.gc.ca/amicus/index-e.html

${ }^{39}$ See "Notable Gifts to M'Gill Library."

${ }^{40}$ Borthwick, History of the Diocese of Montreal, 121.

${ }^{41} \mathrm{E}$-mail communication from L'équipe de recherche de la Direction du Centre d'archives de Montréal et des archives privées, judiciaires et civiles to Svetlana Kochkina, September 23, 2011.
${ }^{42}$ E-mail communication from Ilene McKenna Reference Archivist, Reference Services /Service de référence Information and Research Services Division/ Division des services de l'information et de la recherche Library and Archives Canada / Bibliothèque et Archives Canada to Svetlana Kochkina, October 31, 2011.

${ }^{43}$ Canada Deposit Insurance Corporation. History of Member Institution Failures. http://www.cdic.ca/WhereInsured/FailureHistory/Pages/ default.aspx

${ }^{44}$ Atherton and Joubert, Montreal, 1535-1914, v. 3, 209.

${ }^{45}$ Letter of 2 May 1941 to University Librarian G.R. Lomer from Crown Trust Company. Atherton and Joubert, Montreal, 1535-1914, v. 3, 209.

${ }^{46}$ Peter Lane, Laina Hall, and Susannah Helman. "Stories of sadness and loss". Website of the National Museum of Australia. http://www.nma. gov.au/audio/transcripts/NMA_Hall_20090613.html. Letter from Samuel Bromley to Thomas Mussen, Jan 1867. Website of the National Museum of Australia. http://www.nma.gov.au/collections-search/ display?irn=128126. Collection of autograph letters and ephemera relating to the gold fields of New South Wales and the killing of Alexander Mussen by bushrangers. Christie's sale 4073/ lot $60 \mathrm{http}: / /$ www.christies.com/ LotFinder/lot_details.aspx?intObjectID $=4787229$.

${ }^{47}$ Report (Missisquoi County Historical Society), (Stanbridge East, Québec: Missisquoi County Historical Society, 1899-1913).

${ }^{48} \mathrm{E}$-mail communication from Arlene Royea, Managing Director of Brome County Historical Society to Svetlana Kochkina, May 26, 2011.

${ }^{49}$ Yvan Lamonde, Patricia Fleming, and American Antiquarian Society, Cultural Crossroads: Print and Reading in Eighteenth-and Nineteenth-Century Montreal (Worcester: American Antiquarian Society, 2004). Lamonde, Yvan, and Sophie Montreuil, Lire Au Québec Au XIXe Siècle (Saint-Laurent, Québec: Fides, 2003). Yvan Lamonde, Daniel Olivier, and Lawrence M. Lande, Les Bibliothèques Personnelles Au Québec: Inventaire Analytique Et Préliminaire Des Sources (Montréal: Ministère des affaires culturelles, Bibliothèque nationale du Québec, 1983). Marcel Lajeunesse, «Personal Libraries and Bibliophilia,» in History of the Book in Canada, ed. Fleming et al. (Toronto: University of Toronto Press, 2004), vol. 1, 202-206. Yvan Lamonde and Andrea Rotundo, "Entering Personal Libraries," in History of the Book in Canada, ed. Fleming et al., (Toronto: University of Toronto Press, 2004), vol. 2, 243-246.

${ }^{50}$ William Osler, Bibliotheca Osleriana: a Catalogue of Books Illustrating the History of Medicine and Science, (Montreal: McGill-Queen's University Press, 1969), xxvii. 